\title{
Food systems leadership: A neglected field
}

\author{
Keith Williams* \\ First Nations Technical Institute and \\ St. Francis Xavier University
}

Review of F ood L eadership: L eadership and A dult L earning for $\mathrm{G}$ lobal F ood Systems Transformation, edited by Catherine Etmanski. (2017). Published by Sense Publishers.

Available as hardcover, paperback, and ebook; 190 pages. Publisher's website: https:/ / www.sensepublishers.com/ catalogs/ bookseries/ international-issues-in-adult-education/ food-leadership/

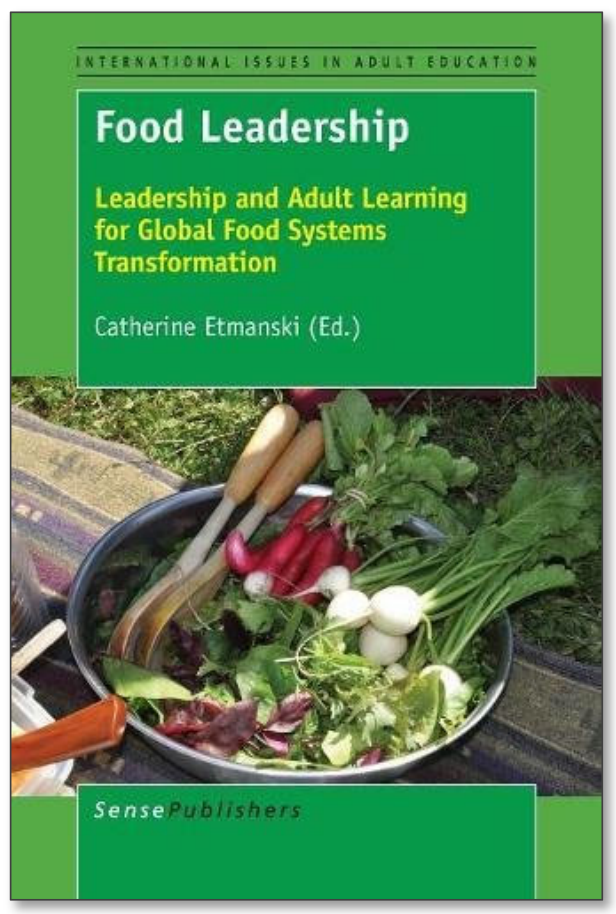

Submitted May 16, 2018 / Published online June 26, 2018

Citation: Williams, K. (2018). Food systems leadership: A neglected field [Book review]. Journal of A griculture, F ood Systems, and C ommunity D evelopment, 8(2), 165-169. https:/ / doi.org/ 10.5304/ jafscd.2018.082.016

Copyright @ 2018 by the Author. Published by the Lyson Center for Civic Agriculture and Food Systems. Open access under CC BY license.

H ood L eadership: L eadership and A dult L earning for $1 \mathrm{G}$ lobal Food Systems, edited by Catherine Etmanski (2017), consists of eight papers in three sections: Indigenous food systems, leadership in

* Keith Williams, Special Projects Advisor, First Nations Technical Institute; 3 Old Y ork Road; D eseronto, Ontario, K0K $1 X 0$ Canada; and doctoral student, St. Francis Xavier University; Antigonish, Nova Scotia, B2G 2W5 Canada. Keith Williams is currently a special projects advisor with the First Nations Technical Institute in Tyendinaga Mohawk Territory, and a doctoral student at St Francis X avier University, Nova Scotia. Keith is interested in sustainable food systems and food sovereignty and can be reached at keithw@ fnti.net or x2017vpd@ stfx.ca global food system transformation, and learning in global food system transformation. Leadership, although a contested concept (G rint, 2005), has been broadly defined by Bass and Bass (2008) as "the ability to influence, motivate, and enable others to contribute to the effectiveness and success of the organizations of which they are members" (p. 23). Global food insecurity remains a persistent problem despite decades of intervention and billions of dollars of investment (Barrett, 2010; Rosegrant, Paisner, Meijer, \& Witcover, 2001); yet, very little research has focused on leadership for food system transformation (Etmanski, 2017). This 
volume presents a long overdue treatment of an important yet neglected subject.

The Indigenous food systems section begins with Adrianne Lickers Xavier's discussion of the Our Sustenanœ initiative in Six Nations, her home community. The 0 ur Sustenance initiative has two main foci: food access and education. It comprises several programs, including a farmers market, Good Food Box program, a community garden, and a greenhouse. Lickers X avier notes that, in Six Nations, food security is addressed on cultural, social, and community levels. This reflects the holistic nature of food in Haudenosaunee culture and suggests that food systems initiatives need to inhabit a range of societal domains to be successful in Haudenosaunee communities.

Lickers X avier introduces the "Three Sisters" agriculture system common to the Haudenosaunee and other Indigenous communities in North America (Trotman Martinez, 2007). She explores the cultural and ecological significance and role of each "sister" - corn, beans, and squash - revealing the genius of the Three Sisters polyculture system. Lickers X avier's description of the 0 ur Sustenance initiative and its integration into the lives of Six Nations community members provides a snapshot of the cultural context of a fulsome and inspiring contemporary Indigenous food systems initiative.

In chapter three of the Indigenous Food Systems section, Reader and D ew Johnson describe the devastating impacts of the residential school system on the Tohono O 'odham community, specifically regarding the loss of traditional food knowledge and practices. Historical trauma associated with residential schools, as the authors suggest, negatively affects contemporary Indigenous perception of, and engagement in, education. This important point, among others, justifies radical approaches to decolonizing Indigenous education. In this chapter, the authors profile the $\mathrm{N}$ ew $\mathrm{G}$ eneration of 0 'odham Farmers program, a communitybased food sovereignty program that utilizes a culturally appropriate pedagogic model to re-build the Tohono O'odham food system. The $\mathrm{N}$ ew $\mathrm{G}$ eneration program consists of two farms that produce traditional foods, a wild food program, school gardens and associated curriculum, a food service social enterprise, an affordable traditional foods café, and various educational and cultural events.

The $\mathrm{N}$ ew $\mathrm{G}$ eneration program employs a transformative learning model with three elements: (1) an experiential and critical approach drawing on Freire's (1970) idea of onscientization, which combines critical reflection and action to raise students' consciousness; (2) recognition of the complexity of Indigenous agricultural knowledge and its adaptive application to equally complex environments; and (3) experimentation to rediscover lost traditional knowledge. The authors refer to their model as transformative, and they provide evidence of the transformative impact of this work, but they do not connect their model to Mezirow's transformative learning theory (1991). It would be valuable for other educators to have a sense of the extent to which Mezirow's theory is culturally appropriate for Indigenous contexts. This well-written chapter, reporting on an exciting and innovative Indigenous food sovereignty initiative, makes an important contribution to our understanding of culturally relevant pedagogy for food system transformation.

Several themes, common to all of the chapters in this section, reveal some of the pressing issues and aspirations present in the three Indigenous cultures discussed. The impacts of culture loss on traditional food systems, the importance of informal and experiential learning, risks associated with genetically modified crops and the importance of the genetic diversity of Indigenous crop varieties, and the specificity of Indigenous agroecological adaptive cropping systems are highlighted. Finally, each article presents a hopeful vision of a future in which Indigenous communities regain sovereignty over their own food systems, revitalize traditional food knowledge, and foster healthier communities through increased consumption of traditional foods and engagement in traditional food practices.

In chapter 4 of the Leadership in Global Food Systems Transformation section, D ay Farnsworth interrogates the disconnect between the food justice values espoused by food policy councils (FPCs) and the practices they enact. The author points out a key tension around structure and purpose: should FPCs operate as governmental or arms-length de facto "departments of food" or should they function as community-based grass- 
roots organizations- or something in between? The model adopted by a given FPC impacts the organizational culture and governance approach, which can ultimately influence the extent to which food justice is enacted.

D ay Farnsworth suggests that organizational governance suited to managing organizations is not always compatible with governance approaches necessary to run grassroots initiatives, and that the increasing professionalization of FPCs has resulted in the adoption of more bureaucratic governance models. D ay Farnsworth advances that FPC organizational structures and processes must support grassroots needs and aspirations rather than self-serving bureaucracy. The author makes a few practical suggestions, such as offering antioppression training to FPC members and expanding membership categories for appointment-based FPCs.

Langer's chapter, in the final section, explores the co-option of nonprofit activities by external bureaucratic demands. He presents a sympathetic view of the harried nonprofit coordinator without time to deconstruct the implications of the various organizational frames (e.g., municipal regulations) to which the organization is subjected, which may undermine its ability to serve its client population.

Langer introduces various organizational frames or discourses that influence garden coordinators and sublimate the needs of garden clients suffering from food insecurity. A notable discourse associated with nonprofits conflates poverty and hunger. The community garden nonprofit frame is directed by a focus on hunger as a proxy for poverty and is beholden to, among other things, the bureaucratic machinery necessary for nonprofit functioning (e.g., salaries for staff). Langer draws on Freire's (1970) concept of conscientization to suggest that nonprofit coordinators should improve their critical institutional literacy, which is essentially a set of skills that allows individuals to "challenge oppressive institutional structures more effectively" (p. 126), allowing garden coordinators to refocus on the needs of their client population. The insights presented by D ay Farnsworth and

1 Social innovation involves the application of a suite of tools, concepts, or services that have the potential to enhance the
Langer in their respective chapters could help nonprofit actors to re-orient their work for the benefit of the communities they serve.

In the conclusion, $\mathrm{G}$ oodall and Etmanski profile examples of social innovation ${ }^{1}$ and evaluation in food system initiatives. Although social innovation presents tantalizing possibilities for addressing food system inequities, it arguably does so within a neoliberal framework (Brown, 2015) that emphasizes individualist agency and accountability within a capitalist market structure. While this may be suitable for incremental food system changes, social innovation may not yield the kind of profound changes advocated by some thinkers (Akram-Lodhi, 2013) and is not necessarily compatible with Indigenous worldviews that emphasize the importance of relationality and reciprocity with the human and more-than-human community (Sheridan \& Longboat, 2006; Weber-Pillwax, 2001).

Agroecology - a lens for viewing the food system that encompasses both social and ecological dimensions - has been adopted as the agronomic standard by L a $\mathrm{V}$ ia C ampesina, a transnational network of approximately 100,000 farmers and farm activists from 69 countries (Foran et al., 2014). G oodall and Etmanski suggest employing permaculture principles to food system leadership. Permaculture, a subset of agroecology, is an approach to the design of food-producing ecosystems that has achieved a level of popularity, primarily in the alternative food system community (Ferguson \& Lowell, 2014). Ferguson and Lowell (2014), however, caution against permaculture's emphasis on individual agency as playing a depoliticizing role in the food system. Several researchers have applied permaculture principles to leadership practices; Mannen et al. (2012) and Henfrey (2018) provide evidence that permaculture principles, when applied at the organizational and community levels, can increase the resilience of those human systems. Madjidi (2014) conceives of 'inner permaculture' as a leadership approach to catalyzing a transformation of the human-nature relationship. More empirical and theoretical work is required to

well-being of individuals, communities, or society (Westley, Antadze, Riddell, Robinson, \& G eobey, 2014). 
develop permaculture principles into a comprehensive leadership theory with the capacity to address the complex socio-ecological challenges associated with food system transformation.

This volume breaks new academic ground, building on Kaak's (2012) article on sustainable food systems and leadership. Although this may be the first volume of work on adult education and sustainable food systems, there is a wealth of research on agriculture education and leadership conducted through agriculture and agriculture education departments in the U.S. land-grant college system (e.g., Greiman, 2009; Jordan, Buchanan, Clarke, \& Jordan, 2013). However, much of this research is positivist and productionist in orientation rather than focusing on holistic food systems; consequently, such research addresses different questions than those typically posed by researchers who subscribe to an alternative vision of the food system. O nly one of the papers in this volume, D as Gupta's assessment of Narendra Modi's leadership style, draws from the voluminous body of leadership theory, specifically transformational leadership (Bass, 1985).

The lack of reference to broader leadership research suggests that the contributing authors are food system researchers rather than leadership, or food system leadership, researchers. A more deliberate infusion of leadership research will help the nascent field of food systems leadership to build on appropriate elements from the leadership field and/ or define itself against contemporary leadership theory. F ood L eadership: L eadership and A dult L earning for G lobal F ood Systems Transformation lays the groundwork for further research in food systems leadership, provokes us to think about food systems leadership in new ways, and presents us with practical suggestions for enhancing leadership functions in food system organizations.

\section{References}

Akram-Lodhi, A. H. (2013). H ungry for change: Farmers, food justice, and the agrarian question. Halifax, Nova Scotia: Fernwood Publishing.

Barrett, C. B. (2010). Measuring food insecurity. Science, 327(5967), 825-828. https:/ / doi.org/ 10.1126/ science.1182768

Bass, B. M. (1985). L eadership and performance beyond ex pedations. New Y ork: Free Press.

Bass, B. M., \& Bass, R. (2008). The Bass handbook of leadership: Theory, research, \& managerial applications (4th ed.). New Y ork: Free Press.

Brown, W. (2015). U ndoing the demos: N eoliberalism's stealth revolution. Brooklyn, New York: Zone Books.

Ferguson, R. S., \& Lowell, S. T. (2014). Permaculture for agroecology: D esign, movement, practice, and worldview. A review. A gronomy and Sustainable D evelopment, 34(2), 251-274. https:/ / doi.org/ 10.1007/ s13593-013-0181-6

Foran, T., Butler, J. R. A., Williams, L. J., Wanjurra, W. J., Hall, A., Carter, L., \& Carberry, P. S. (2014). Taking complexity in food systems seriously: An interdisciplinary analysis. W orld D evelopment, 61, 85-101. https:/ / doi.org/ 10.1016/ j.worlddev.2014.03.023

Freire, P. (1968/ 1970). Pedagogy of the oppressed. (M. Ramos, Trans.). New York: Continuum.

Greiman, B. C. (2009). Transformational leadership research in agriculture education: A synthesis of the literature. Journal of A griaultural E ducation, 50(4), 50-62. http:/ / www.jae-online.org/

Grint, K. (2005). L eadership: L imits and possibilities. Aldershot, UK: Palgrave Macmillan.

Henfrey, T. W. (2018). Designing for resilience: Permaculture as a transdisciplinary methodology in applied resilience research. E cology and Society, 23(2), 33. https:/ / doi.org/ 10.5751/ ES-09916-230233

Jordan, J. P., Buchanan, G . A., Clarke, N. P., \& Jordan, K. C. (2013). L eadership in agriculture: Case studies for a new generation. College Station: Texas A\&M University Press.

Kaak, P. (2012). Leadership for sustainable food systems. In D . R. G allagher (Ed.), E nvironmental leadership: A referenœ handbook (pp. 761-770). Thousand O aks, CA: Sage.

Madjidi, K.S. (2014). The ecology of transformation: A relational study of the ecology of leadership program at the Regenerative D esign Institute (D octoral dissertation). Ontario Institute for Studies in Education.

Mannen, D., Hinton, S., Kuijper, T., \& Porter, T. (2012). Sustainable organizing: A multiparadigm perspective of organizational development and permaculture gardening. Journal of L eadership \& O rganizational Studies, 19(3), 355368. https:/ / doi.org/ 10.1177/ 1548051812442967 
Mezirow, J. (1991). Transformative dimensions of adult learning. San Francisco: Jossey Bass.

Rosegrant, M. W., Paisner, M. S., Meijer, S., \& Witcover, J. (2001). G lobal food projections to 2020: E merging trends and alternative futures. Washington, D.C.: International Food Policy Research Institute. Retrieved from http:// pdf.usaid.gov/ pdf docs/ PNACM469.pdf

Sheridan, J., \& Longboat, D . (2006). The Haudenosaunee imagination and the ecology of the sacred. Spac and Culture, 9(4), 365-381. https:/ / doi.org/ 10.1177/ 1206331206292503

Trotman Martinez, R. (2007). A n evaluation of the productivity of the $\mathrm{N}$ ative A merican 'T hree Sisters' agrialture system in northern W isonsin. (Unpublished master's thesis). University of Wisconsin, Steven's Point. Retrieved from https:/ / epapers.uwsp.edu/ thesis/ 2007/ Martinez.pdf

Weber-Pillwax, C. (2001). What is Indigenous research? Canadian Journal of $\mathrm{N}$ ative $\mathrm{E}$ ducation, 25(2), 166-174.

Westley, F., Antadze, N., Riddell, D. J., Robinson, K., \& G eobey, S. (2014). Five configurations for scaling up social innovation: Case examples from nonprofit organizations from Canada. Journal of A pplied Behavioral Science, 50(3), 234-260. https:/ / doi.org/ 10.1177/ 0021886314532945 